\title{
Studying the Interrelationship amongst various Success Factors for Implementing Six Sigma in Indian Manufacturing SMEs
}

\author{
P. C. Jha \\ Department of Operational \\ Research \\ Faculty of Mathematical Sciences, \\ University of Delhi \\ Delhi, India
}

\author{
Remica Aggarwal \\ School of Business, University of \\ Petroleum \& Energy Studies \\ Dehradun, India
}

\author{
Bhoomica Aggarwal \\ HCL Technologies, Sector 125 \\ Noida, India
}

\begin{abstract}
Present research explores various critical success factors for successful implementation of six sigma methodology to Indian small medium enterprises of manufacturing sector . It further tries to study the interrelationship amongst them using ISM methodology.
\end{abstract}

\section{Keywords}

Small medium enterprises; Interpretive structural modelling methodology; Six sigma technique; Manufacturing sector

\section{INTRODUCTION}

Six-Sigma is an improvement philosophy in quality management to make enterprises more competitive with the aim of achieving further business excellence [1-5]. Six Sigma approach improves the quality of products in order to ensure customers' satisfaction and has yielded interesting and positive results for large enterprises. However, its implementation remains difficult for small- and medium-sized enterprises (SME)[6-9]. In fact, the use of the same tools is insufficient to achieve the objectives when considering financial constraints and the lack of data. A number of tools and techniques are highlighted by researchers for six sigma implementation using DMAIC and DMADV approach. Some of them are supplier input-output control (SIPOC) process mapping, quality function deployment (QFD), failure mode and effect analysis (FMEA), pareto analysis , process capability analysis , benchmarking, design of experiment , cause and effect analysis. However these regular tools are complex for SMEs which require an adapted model to implement the approach successfully. Manufacturing organization improves profitability and customer satisfaction by implementing this methodology. In manufacturing organizations, six sigma is used to streamline manufacturing processes . It works for process improvement, process design and process management, reducing variations in the process. The main objectives of the present research work includes exploring various metrics for successful implementation of six sigma methodology for SMEs and further studying the interrelationship amongst them using ISM methodology. Present research work is organized as follows : Section 2 reviews the associated literature. Section 3 presents the ISM methodology. Section 4 studies the case example and finally managerial implications are presented in section 5 .

\section{LITERATURE REVIEW}

Since, the origin of Six Sigma, increasing competitiveness of organization seems to be extremely common in the sectors of business [10-12]. Stanklla et al. [12] critically review various critical factors for successful implementation of six sigma in SMEs. This reference reviews the articles from countries such as Australia [13] , UK[14-16] , India [17-22], Pakistan $[23,24]$, Taiwan $[26,27]$ to identify various critical success factors for implementing six sigma in small and medium sized enterprises. For example , [13] describes the critical successfactors with respect to Australian SMEs The three critical success factors (CSFs) viz. linkage between six sigma and customer - management commitment, involvement and participation and linkage between six sigma and business strategy of an enterprise were found crucial CSFs for implementing six sigma effectively within UK manufacturing small medium enterprises [14-16] . Ertuck [25] , Cheng $[26,27]$ investigated six sigma activities and presented performance and managerial variables for the industrial surroundings in Taiwan . Managerial variables(independent) included the factors of customer, strategy, training and project whereas the performance variables(dependent) include the factors of cost, delivery, quality and flexibility . Cheng [27] examined the relationship between business strategy and Six Sigma in Taiwan. Tyagi et al. [19] evaluate the critical success factors with respect to Indian manufacturing SMEs . This research evaluate and present the results from the online survey conducted in various Indian manufacturing small and medium enterprises mainly to focus CSFs for implementing six sigma in these SMEs. The results are further investigated by the factor analysis . Summary of identified critical success factors from published literature have been compiled and mentioned in table 1 given below 
Table I : Critical success factors for successful implementation of Six sigma in SMEs

\begin{tabular}{|c|c|c|c|}
\hline $\begin{array}{c}\text { S. } \\
\text { No. }\end{array}$ & $\begin{array}{l}\text { Success } \\
\text { factors }\end{array}$ & Description & Reference \\
\hline 1. & $\begin{array}{c}\text { Management } \\
\text { involvement } \\
\text { and } \\
\text { participation } \\
\text { (MIP) / } \\
\text { management } \\
\text { commitment / } \\
\text { management } \\
\text { support }\end{array}$ & $\begin{array}{l}\text { Without continuous } \\
\text { involvement and } \\
\text { support from top } \\
\text { management, six } \\
\text { sigma‘s successful } \\
\text { implementation is } \\
\text { not possible. }\end{array}$ & $\begin{array}{l}{[14],[29],} \\
[30], 31], \\
{[32],[33]}\end{array}$ \\
\hline 2. & $\begin{array}{c}\text { A well- } \\
\text { implemented } \\
\text { customer } \\
\text { management } \\
\text { system / } \\
\text { associating six } \\
\text { sigma with } \\
\text { customers and } \\
\text { market needs } \\
\text { / identifying } \\
\text { customer } \\
\text { needs (ICN) }\end{array}$ & $\begin{array}{c}\text { To identify core } \\
\text { business relations } \\
\text { and customer needs } \\
\text { are critical to quality } \\
\text { characteristics . } \\
\text { QFD is the best } \\
\text { technique to } \\
\text { understand the } \\
\text { business needs and } \\
\text { expectations of } \\
\text { customers and } \\
\text { translate into core } \\
\text { business activities. }\end{array}$ & $\begin{array}{c}\text { [34], [32], [33], } \\
{[16],[23],[26]}\end{array}$ \\
\hline 3. & $\begin{array}{l}\text { The education } \\
\text { and training } \\
\text { about six } \\
\text { sigma and } \\
\text { methodology } \\
\text { (ETS)/ } \\
\text { understanding } \\
\text { six sigma } \\
\text { methodology }\end{array}$ & $\begin{array}{c}\text { When an } \\
\text { organisation trains } \\
\text { and educate people } \\
\text { and realizes the } \\
\text { employees as } \\
\text { integral part of } \\
\text { organisation, six } \\
\text { sigma and other } \\
\text { quality tool can give } \\
\text { the best results. }\end{array}$ & [34] \\
\hline 4. & $\begin{array}{c}\text { A well- } \\
\text { implemented } \\
\text { process } \\
\text { management } \\
\text { system } \\
\text { (PMS)/ } \\
\text { identifying } \\
\text { core processes } \\
\text { and measures / } \\
\text { process } \\
\text { mapping or re- } \\
\text { engineering }\end{array}$ & $\begin{array}{c}\text { Process mapping } \\
\text { and reengineering } \\
\text { helps to create } \\
\text { workflow diagram to } \\
\text { highlight each and } \\
\text { every stage included } \\
\text { in the process and } \\
\text { its parallel processes } \\
\text {, which help to } \\
\text { identify processes or } \\
\text { activities which are } \\
\text { of value added and } \\
\text { which should be } \\
\text { removed. }\end{array}$ & [35] \\
\hline 5. & $\begin{array}{c}\text { A well- } \\
\text { developed } \\
\text { supplier } \\
\text { management } \\
\text { system (SMS) } \\
\text {; linking six } \\
\text { sigma to } \\
\text { suppliers }\end{array}$ & $\begin{array}{l}\text { Strong involvement } \\
\text { of suppliers in six } \\
\text { sigma program can } \\
\text { be beneficial for an } \\
\text { organization to bring } \\
\text { supplier closer to the } \\
\text { customer to } \\
\text { improve the quality } \\
\text { of product or } \\
\text { process. Six sigma } \\
\text { methodology also } \\
\text { explains that to } \\
\text { reduce variability in }\end{array}$ & [23] \\
\hline
\end{tabular}

\begin{tabular}{|c|c|c|c|}
\hline & & $\begin{array}{l}\text { the process, your } \\
\text { organisations need } \\
\text { to have few } \\
\text { suppliers. }\end{array}$ & \\
\hline 6. & $\begin{array}{c}\text { A well- } \\
\text { developed } \\
\text { human } \\
\text { resource } \\
\text { management } \\
\text { system } \\
\text { (HRMS); } \\
\text { associating six } \\
\text { sigma with } \\
\text { employees }\end{array}$ & $\begin{array}{l}\text { Selection of right } \\
\text { candidate with } \\
\text { appropriate } \\
\text { knowledge and } \\
\text { training are the most } \\
\text { critical factor for } \\
\text { successful } \\
\text { implementation of } \\
\text { six sigma. Further } \\
\text { in any organization, } \\
\text { projects can only be } \\
\text { successfully } \\
\text { implemented if the } \\
\text { employees involved } \\
\text { in the projects are in } \\
\text { collaboration with } \\
\text { each other while } \\
\text { sharing knowledge } \\
\text { and data. }\end{array}$ & [23] \\
\hline 7. & $\begin{array}{l}\text { Organizational } \\
\text { infrastructure / } \\
\text { readiness } \\
\text { (OIR) }\end{array}$ & $\begin{array}{l}\text { Implementation of } \\
\text { six sigma } \\
\text { methodology in any } \\
\text { organization } \\
\text { requires completely } \\
\text { dedicated employees } \\
\text { and cross functional } \\
\text { teams and } \\
\text { facilitative } \\
\text { leadership } \\
\text { behaviour. }\end{array}$ & [23] \\
\hline 8. & $\begin{array}{l}\text { Linking six } \\
\text { sigma to } \\
\text { business } \\
\text { strategy (LSS) }\end{array}$ & $\begin{array}{l}\text { Top leaders have to } \\
\text { ensure that six sigma } \\
\text { is the best strategy } \\
\text { for process } \\
\text { improvement and } \\
\text { must be sustained } \\
\text { before during and } \\
\text { after the } \\
\text { implementation of } \\
\text { the process. }\end{array}$ & {$[34],[22]$} \\
\hline 9. & $\begin{array}{c}\text { Project } \\
\text { prioritisation, } \\
\text { planning and } \\
\text { selection } \\
\text { (PPS) }\end{array}$ & $\begin{array}{l}\text { Project planning and } \\
\text { selection should } \\
\text { always be aligned } \\
\text { with company's } \\
\text { strategies . Poorly } \\
\text { aligned and incorrect } \\
\text { project selection } \\
\text { leads to loss in } \\
\text { business and } \\
\text { eventually creep into } \\
\text { frustation. Most of } \\
\text { the projects failed to } \\
\text { complete owing to } \\
\text { the non- adherence } \\
\text { to the guidelines and } \\
\text { deadlines of its } \\
\text { phase completion }\end{array}$ & {$[34],[33],[22]$} \\
\hline 10. & $\begin{array}{l}\text { Management } \\
\text { skills for } \\
\text { handling }\end{array}$ & $\begin{array}{l}\text { Managers should } \\
\text { inculcate good } \\
\text { project management }\end{array}$ & [23] \\
\hline
\end{tabular}




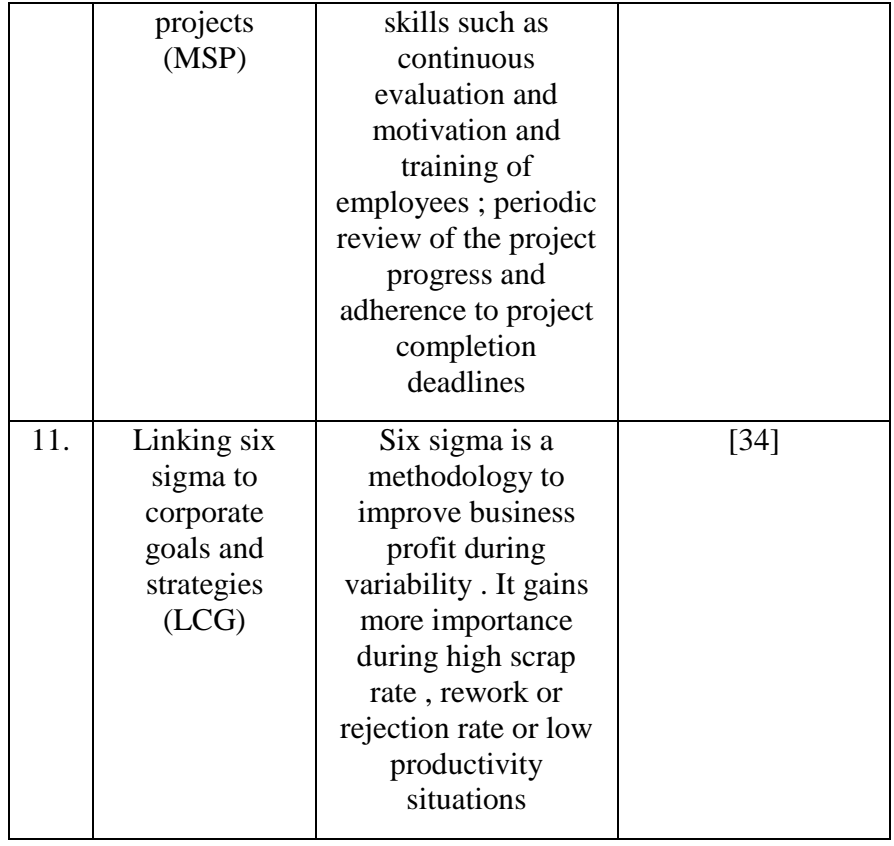

\section{INTERPRETIVE STRUCTURAL MODELLING METHODOLOGY}

Suggested by Warfield [ ], the technique has been used widely to develop a map of the relationships between the many elements in the form of a hierarchy graph. Group's judgement decides whether and how the items are related. ISM works with the following steps. It deals with the identification of elements, which are relevant to the decision maker's problems and issues. Thereafter, it establish the contextual relationship between elements and with respect to which pairs of elements will be examine. A structural selfinteraction matrix (SSIM) may be developed afterwards between two variables i.e. i and j. It establishes the "Lead to" relationship between criteria. Four symbols viz. V, A, X \& $\mathrm{O}$ are used for establishing the relationships. SSIM may be further used to develop an initial reachability matrix which has all values in binary form. Rule of transitivity is usually checked at this stage. After removing the transitivity, final reachability matrix will form. Afterwards, the reachability set and antecedent set for each criterion and for each element can be obtained from the final reachability matrix. After that a level partition matrix can be obtained based on establishing the precedence relationships and arranging the elements in a topological order. A Mic-Mac analysis can be performed which categorize the variables as per the driving and dependence power in to autonomous, dependent, driver and linkage category. Finally a diagraph can be obtained.

\section{DEVELOPMENT OF ISM MODEL}

Based on the literature review presented above , 11 identified success factors viz . Management involvement and participation (MIP); Identifying customer needs (ICN); education and training about six sigma and methodology (ETS) ; process management system (PMS) ; supplier management system (SMS) ; human resource management system (HRMS); Organizational infrastructure / readiness (OIR) ; Linking six sigma to business strategy (LSS); Project prioritization, planning and selection (PPS) ; management skills related to project handling (MSP) ; Linking six sigma to corporate goals and strategies (LCG) are further analysed through ISM methodology for their possible interrelation and dependencies.

\subsection{Construction of Structural Self - Interaction Matrix (SSIM)}

This matrix gives the pair-wise relationship between two variables i.e. $i$ and $j$ based on VAXO. SSIM has been presented below in Fig 1.

\subsection{Construction of Initial Reachability Matrix and final reachability matrix}

The SSIM has been converted in to a binary matrix called the initial reachability matrix shown in fig. 2 by substituting V, A, $\mathrm{X}, \mathrm{O}$ by 1 or 0 as per the case. After incorporating the transitivity, the final reachability matrix is shown below in the Fig 3.

Fig 1: SSIM matrix for pair wise relationship amongst various success factors

\begin{tabular}{|c|c|c|c|c|c|c|c|c|c|c|c|c|}
\hline $\begin{array}{c}\text { Barri } \\
\text { ers }\end{array}$ & & 1 & 2 & 3 & 4 & 5 & 6 & 7 & 8 & 9 & 10 & 11 \\
\hline & & MIP & ICN & ETS & PMS & SMS & $\begin{array}{c}\text { HR } \\
\text { MS }\end{array}$ & OIR & LSS & PPS & MSP & LCG \\
\hline 1. & MIP & & $\mathrm{V}$ & $\mathrm{V}$ & $\mathrm{V}$ & $\mathrm{V}$ & $\mathrm{V}$ & $\mathrm{X}$ & $\mathrm{X}$ & $\mathrm{V}$ & $\mathrm{V}$ & $\mathrm{V}$ \\
\hline 2. & $\mathrm{ICN}$ & & & $\mathrm{X}$ & $\mathrm{A}$ & $\mathrm{X}$ & $\mathrm{X}$ & $\mathrm{A}$ & $\mathrm{V}$ & $\mathrm{V}$ & $\mathrm{A}$ & $\mathrm{A}$ \\
\hline 3. & ETS & & & $\mathrm{V}$ & $\mathrm{V}$ & $\mathrm{V}$ & $\mathrm{V}$ & $\mathrm{V}$ & $\mathrm{V}$ & $\mathrm{V}$ & $\mathrm{V}$ \\
\hline 4. & PMS & & & & $\mathrm{O}$ & $\mathrm{X}$ & $\mathrm{A}$ & $\mathrm{O}$ & $\mathrm{A}$ & $\mathrm{A}$ & $\mathrm{A}$ \\
\hline 5. & SMS & & & & & & $\mathrm{O}$ & $\mathrm{A}$ & $\mathrm{A}$ & $\mathrm{A}$ & $\mathrm{A}$ & $\mathrm{A}$ \\
\hline 6. & HRMS & & & & & & & $\mathrm{A}$ & $\mathrm{A}$ & $\mathrm{A}$ & $\mathrm{A}$ & $\mathrm{A}$ \\
\hline 7. & OIR & & & & & & & & $\mathrm{V}$ & $\mathrm{V}$ & $\mathrm{V}$ & $\mathrm{V}$ \\
\hline 8. & LSS & & & & & & & & $\mathrm{A}$ & $\mathrm{A}$ & $\mathrm{X}$ \\
\hline 9. & PPS & & & & & & & & & $\mathrm{A}$ & $\mathrm{X}$ \\
\hline 10. & MSP & & & & & & & & & & $\mathrm{V}$ \\
\hline 11. & LCG & & & & & & & & & & & \\
\hline
\end{tabular}


Fig 2: Initial reachability matrix

\begin{tabular}{|c|c|c|c|c|c|c|c|c|c|c|c|c|}
\hline $\begin{array}{c}\text { Barri } \\
\text { ers }\end{array}$ & & 1 & 2 & 3 & 4 & 5 & 6 & 7 & 8 & 9 & 10 & 11 \\
\hline & & MIP & ICN & ETS & PMS & SMS & $\begin{array}{l}\text { HR } \\
\text { MS }\end{array}$ & OIR & LSS & PPS & MSP & LCG \\
\hline 1. & MIP & 1 & 1 & 1 & 1 & 1 & 1 & 1 & 1 & 1 & 1 & 1 \\
\hline 2. & ICN & 0 & 1 & 1 & 0 & 1 & 1 & 0 & 1 & 1 & 0 & 0 \\
\hline 3. & ETS & 0 & 1 & 1 & 1 & 1 & 1 & 1 & 1 & 1 & 1 & 1 \\
\hline 4. & PMS & 0 & 1 & 0 & 1 & 0 & 1 & 0 & 0 & 0 & 0 & 0 \\
\hline 5. & SMS & 0 & 1 & 0 & 0 & 1 & 0 & 0 & 0 & 0 & 0 & 0 \\
\hline 6. & HRMS & 0 & 1 & 0 & 1 & 0 & 1 & 0 & 0 & 0 & 0 & 0 \\
\hline 7. & OIR & 1 & 1 & 0 & 1 & 1 & 1 & 1 & 1 & 1 & 1 & 1 \\
\hline 8. & LSS & 1 & 0 & 0 & 0 & 1 & 1 & 0 & 1 & 0 & 0 & 1 \\
\hline 9. & PPS & 0 & 0 & 0 & 1 & 1 & 1 & 0 & 1 & 1 & 0 & 1 \\
\hline 10. & MSP & 0 & 1 & 0 & 1 & 1 & 1 & 0 & 1 & 1 & 1 & 1 \\
\hline 11. & $\mathrm{LCG}$ & 0 & 1 & 0 & 1 & 1 & 1 & 0 & 1 & 1 & 0 & 1 \\
\hline
\end{tabular}

Fig 3 : Final reachability matrix

\begin{tabular}{|c|c|c|c|c|c|c|c|c|c|c|c|c|c|}
\hline Barriers & & 1 & 2 & 3 & 4 & 5 & 6 & 7 & 8 & 9 & 10 & 11 & D.P \\
\hline & & MIP & ICN & ETS & PMS & SMS & HRMS & OIR & LSS & PPS & MSP & $\mathrm{LCG}$ & \\
\hline 1. & MIP & 1 & 1 & 1 & 1 & 1 & 1 & 1 & 1 & 1 & 1 & 1 & 11 \\
\hline 2. & ICN & 0 & 1 & 1 & 1 & 1 & 1 & 1 & 1 & 1 & 1 & 1 & 10 \\
\hline 3. & ETS & 0 & 1 & 1 & 1 & 1 & 1 & 1 & 1 & 1 & 1 & 1 & 10 \\
\hline 4. & PMS & 0 & 1 & 1 & 1 & 1 & 1 & 0 & 1 & 1 & 0 & 0 & 8 \\
\hline 5. & SMS & 0 & 1 & 1 & 0 & 1 & 1 & 0 & 1 & 1 & 0 & 0 & 6 \\
\hline 6. & HRMS & 0 & 1 & 1 & 1 & 1 & 1 & 0 & 1 & 1 & 0 & 0 & 7 \\
\hline 7. & OIR & 1 & 1 & 1 & 1 & 1 & 1 & 1 & 1 & 1 & 1 & 1 & 11 \\
\hline 8. & LSS & 1 & 1 & 1 & 1 & 1 & 1 & 1 & 1 & 1 & 1 & 1 & 11 \\
\hline 9. & PPS & 0 & 1 & 0 & 1 & 1 & 1 & 0 & 1 & 1 & 0 & 1 & 7 \\
\hline 10. & MSP & 0 & 1 & 1 & 1 & 1 & 1 & 0 & 1 & 1 & 1 & 1 & 8 \\
\hline 11. & $\mathrm{LCG}$ & 0 & 1 & 1 & 1 & 1 & 1 & 0 & 1 & 1 & 0 & 1 & 7 \\
\hline & De.P & 3 & 11 & 10 & 10 & 11 & 11 & 5 & 11 & 11 & 6 & 8 & \\
\hline
\end{tabular}

D.P : Driving power ; De.P : Dependence power 


\subsection{Level Partition}

From the final reachability matrix, reachability and final antecedent set for each factor are found. The element for which the reachability and intersection sets are same are the top-level element in the ISM hierarchy. After the identification of top level element, it is separated out from the other elements and the process continues for next level of elements. Reachability set, antecedent set, intersection set along with different level for elements have been shown below in table 3 to table 7 .

Table 3 : Iteration I

\begin{tabular}{|c|c|c|c|c|}
\hline $\begin{array}{c}\text { S. } \\
\text { No. }\end{array}$ & $\begin{array}{c}\text { Reachability } \\
\text { set }\end{array}$ & $\begin{array}{c}\text { Antecedent } \\
\text { set }\end{array}$ & $\begin{array}{c}\text { Intersection } \\
\text { set }\end{array}$ & $\begin{array}{c}\text { Iteratio } \\
\text { n/ } \\
\text { Levels }\end{array}$ \\
\hline 1 & $2,5,6,8,9$ & $\begin{array}{c}1,2,3,4,5,6,7 \\
, 8,9,10,11\end{array}$ & $\begin{array}{c}2,5,6, \\
8,9\end{array}$ & \\
\hline 2 & $2,3,4,5.6 .8 .9$ & $\begin{array}{c}1,2,3,4.6,7,8 \\
, 10,11\end{array}$ & $2,3,4,6,8$ & \\
\hline 3 & $2,3,4,5,6,8,9,11$ & $\begin{array}{c}1,2,3,7,8,10, \\
11\end{array}$ & $2,3,8,11$ & I \\
\hline 4 & $\begin{array}{c}2,3,4,5,6,8,9,10 \\
, 11\end{array}$ & $1,2,3,7,8,10$ & $2,3,10$ & \\
\hline 5 & $\begin{array}{c}2,3,4,5,6,7,8,9 \\
10,11\end{array}$ & $1,2,3,7,8$ & $2,3,7$ & \\
\hline 6 & $\begin{array}{c}1,2,3,4,5,6,7,8 \\
9,10,11\end{array}$ & $1,7,8$ & $1,7,8$ & \\
\hline
\end{tabular}

Table 4 : Iteration II

\begin{tabular}{|c|c|c|c|c|}
\hline $\begin{array}{c}\text { S. } \\
\mathbf{N} \\
\mathbf{0 .}\end{array}$ & $\begin{array}{c}\text { Reachability } \\
\text { set }\end{array}$ & $\begin{array}{c}\text { Antecedent } \\
\text { set }\end{array}$ & $\begin{array}{c}\text { Intersec } \\
\text { tion set }\end{array}$ & Iteration \\
\hline 2 & $\mathbf{3 , 4}$ & $\begin{array}{c}1,3,4.7,10,1 \\
1\end{array}$ & 3,4 & \\
\hline 3 & $3,4,11$ & $1,3,7,10,11$ & 3,11 & \multirow{2}{*}{ II } \\
\hline 4 & $3,4,10,11$ & $1,3,7,10$ & 3,10 & \multirow{2}{*}{} \\
\hline 5 & $3,4,7,10,11$ & $1,3,7$ & 3,7 & \\
\hline 6 & $1,3,4,7,10,11$ & 1,7 & 1,7 & \\
\hline
\end{tabular}

Table 5 : Iteration III

\begin{tabular}{|c|c|c|c|c|}
\hline S.No. & $\begin{array}{c}\text { Reachability } \\
\text { set }\end{array}$ & $\begin{array}{c}\text { Antecedent } \\
\text { set }\end{array}$ & $\begin{array}{c}\text { Intersection } \\
\text { set }\end{array}$ & $\begin{array}{c}\text { Iterati } \\
\text { on }\end{array}$ \\
\hline 3 & $\mathbf{1 1}$ & $1,7,10,11$ & 11 & \\
\cline { 1 - 4 } & 10,11 & $1,7,10$ & 10 & \multirow{2}{*}{ III } \\
\hline 5 & $7,10,11$ & 1,7 & 7 & \\
\hline 6 & $1,7,10,11$ & 1,7 & 1,7 & \\
\hline
\end{tabular}

Table 6 : Iteration IV

\begin{tabular}{|c|c|c|c|c|}
\hline $\begin{array}{c}\text { S.N } \\
\text { o. }\end{array}$ & $\begin{array}{c}\text { Reachabilit } \\
\text { y set }\end{array}$ & $\begin{array}{c}\text { Antecedent } \\
\text { set }\end{array}$ & $\begin{array}{c}\text { Intersecti } \\
\text { on set }\end{array}$ & $\begin{array}{c}\text { Iteratio } \\
\mathbf{n} / \\
\text { Levels }\end{array}$ \\
\hline 4 & $\mathbf{1 0}$ & $1,7,10$ & 10 & \multirow{2}{*}{ IV } \\
\cline { 1 - 4 } 5 & 7,10 & 1,7 & 7 & \\
\hline 6 & $1,7,10$ & 1,7 & 1,7 & \\
\hline
\end{tabular}

Table 7 : Iteration V

\begin{tabular}{|c|c|c|c|c|}
\hline $\begin{array}{c}\text { Sr. } \\
\text { No. }\end{array}$ & $\begin{array}{c}\text { Reachability } \\
\text { set }\end{array}$ & $\begin{array}{c}\text { Antecedent } \\
\text { set }\end{array}$ & $\begin{array}{c}\text { Intersection } \\
\text { set }\end{array}$ & $\begin{array}{c}\text { Itera } \\
\text { tion }\end{array}$ \\
\hline 5 & 7 & 1,7 & 7 & \multirow{2}{*}{ V } \\
\hline 6 & $\mathbf{1 , 7}$ & 1,7 & 1,7 & \\
\hline
\end{tabular}

\subsection{Classification of factors}

The critical success factors described earlier are classified in to four clusters viz. autonomous factor, dependent factors, linkage factors and independent factors (mentioned in Table XIII below). Fig. 4 below shows the driving power and dominance diagram.

\begin{tabular}{|c|c|c|c|c|c|c|c|c|c|c|c|}
\hline DRIVING & 11 & & VIIP & & OIR & & & & & & LSS \\
\hline POWER & 10 & & & & & & & & & ETS & ICI \\
\hline & 9 & DRIVE & & & & & & & LINKAGE & & \\
\hline & 8 & & & & & UISP & & & & & \\
\hline & 1 & & & & & & & LCG & & PIIS & \begin{tabular}{|l|l|} 
SUIS, \\
HPUSPP
\end{tabular} \\
\hline & 6 & & & & & & & & & & \\
\hline & 5 & & & & & & & & & & \\
\hline & 4 & & & & & & & & DEPENDENT & & \\
\hline & 3 & & & & & & & & & & \\
\hline & 2 & & & & & & & & & & \\
\hline & 1 & & & & & & & & & & \\
\hline & 1 & 2 & 3 & 4 & $j$ & 6 & 1 & 8 & 9 & 10 & 11 \\
\hline & DEPEND & & & & & & & 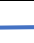 & $\longrightarrow$ & & \\
\hline
\end{tabular}

Fig . 4: Driving power and dependence diagram

\subsection{ISM model}

An ISM model is developed ( as shown in fig. 5 below ) after arranging the elements as per their interaction or dependence relationships. 


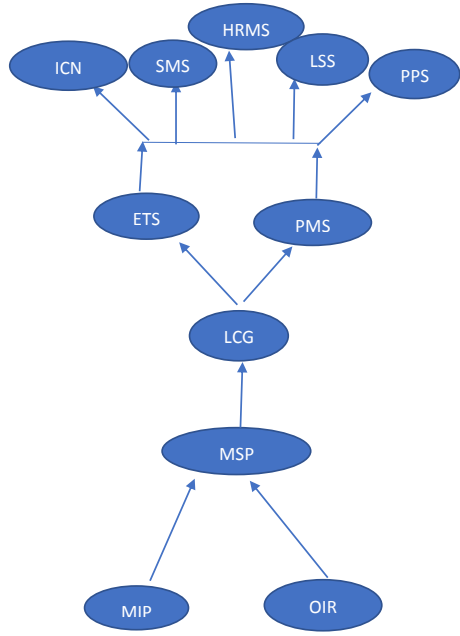

Fig 5: ISM diagraph

\section{MANAGERIAL IMPLICATIONS \& CONCLUSIONS}

Managers could also consider implementing business improvement program such as six sigma to meet the global competition. However its implementation amongst SMEs is a herculean task indeed. The issues faced by SMEs in manufacturing sector for adoption of Six Sigma should be studied and addressed to bring awareness and interest in this breakthrough methodology by the SMEs.

\section{ACKNOWLEDGEMENT}

Authors are thankful to Prof. S.P Singh, Department of Management Studies for imparting knowledge on ISM methodology which helped authors substantially while writing this piece of work.

\section{REFERENCES}

[1] Harry, M.J.,\& Schroeder, R. 2000 . Six Sigma-the breakthrough management strategy revolutionizing the world's top corporations. Doubleday, New York.

[2] Coronado, R.B.,\& Antony, J. 2002.Critical success factors for the successful implementation of Six Sigma projects in organisations. The TQM Magazine, 14, 9298.

[3] Folaron, J. 2003. The evolution of Six Sigma. Six Sigma Forum Magazine, 2, 38-44.

[4] Wessel, C. and Urcher, P.G. 2004. Six sigma for small and medium sized enterprises, the TQM magazine , 16(4) .

[5] Erick, C.J., Mahour, M.P. \& Stephanie, G.A. 2010. A framework for effective Six Sigma implementation. Total Quality Management \& Business Excellence, 21, 415 - 424.

[6] Husband, S. \& Mandal, P. 1999. A conceptual model for quality integrated management in small and medium size enterprises. International Journal of Quality and Reliability Management, 16, 699-713.

[7] Deshmukh, S.V. \& Chavan, A. 2012 .Six Sigma and SMEs: a critical review of literature. International Journal of Lean Six Sigma, 3, 157 - 167.

[8] Kaushik, P., Khanduja, D., Mittal, K. \& Jaglan, P. 2012. A case study: application of Six Sigma methodology in a small and medium-sized manufacturing enterprise. The TQM Journal, 24, 4-16.

[9] Kim, K.S., Knotts, T.L.,\& Jones, S.C. 2008. Characterizing viability of small manufacturing enterprises (SME) in the market. Expert Systems with Applications, 34, 28-134.

[10] Lande, M.S. \& Shrivastava, R. L. 2016. Quality practice model for micro small medium enterprises (MSMEs). Industrial Engineering Journal, 9, 43-46.

[11] Moosa, K. \& Sajid, A. 2010.Critical analysis of Six Sigma implementation. Total Quality Management, 21, $745-59$.

[12] Stankalla, R., Kolval, O. and Chromjakova, F. 2018. A review of critical success factors for the successful implementation of lean six sigma and six sigma in manufacturing small and medium sized enterprises . Journal of quality engineering . Taylor and francis online , 30(3)

[13] Hilton, R., Balla, M. \& Sohal, A.S. 2008 . Factors critical to the success of a Six-Sigma quality program in an Australian hospital. Total Quality Management and Business Excellence, 19, 887-902.

[14] Kumar, M. 2007.Critical success factors and hurdles to Six Sigma implementation: the case of a UK manufacturing SME. International Journal of Six Sigma and Competitive Advantage, 3, 333-51.

[15] Kumar, M., \& Antony, J. 2008. Comparing the quality management practices in UK SMEs. Industrial Management \& Data Systems, 108, 1153 - 1166.

[16] Kumar, M., Antony, J. \& Douglas, A. 2009. Does size matter for Six Sigma implementation? Findings from the survey in UKSMEs. The TQM Journal, 21, 623-35.

[17] Soti, A., Shankar, R.,\& Kaushal, O.P. 2012. Six Sigma in manufacturing for micro, small and medium enterprises in India. International Journal of Productivity and Quality Management, 9, 61-81.

[18] Singh, M.D., Thakur, G.D.,\& Sharma, P. 2015. A Review of Six Sigma implementation Practices in Indian SMEs Particularly in State of Gujarat. Industrial Engineering Journal, 8, 15-21.

[19] Tyagi , D. , Soni , V.K. and Khare , V.K. 2017. Evaluation of critical success factors for six sigma implementation in Indian manufacturing SMEs , International Journal of Mechanical and Production Engineering Research and Development (IJMPERD), ISSN (P): 2249-6890; ISSN (E): 2249-8001, 7(6) , 489500 .

[20] Raghuvanshi, J., Ghosh, P.K., Agrawal, R.\&Gupta, H. 20 17.Hierarchical structure for enhancing the innovation in the MSME sector of India. International Journal of Business Excellence, 13, 181-199.

[21] Raghunath A, Jayathirtha R. V. 2013. Barriers for implementation of Six Sigma by Small and Medium Enterprises, International Journal of Advancements in Research \& Technology, 2(2) .

[22] Desai, D.A., Antony, J.,\& Patel, M.B. 2012. An assessment of the critical success factors for Six Sigma implementation in Indian industries. International Journal of Productivity and Performance Management, 61, 426 - 
444

[23] Kureshi, N., Qureshi, F. \& Sajid, A. 2010.Current health of quality management practices in service sector SME: a Case study of Pakistan. The TQM Journal, 22, 317-29.

[24] Tabassum , Z., Bayraktar , C.A. , Muhammuddin , A. and Duruccu, M. 2016. Analysis of critical success factors of six sigma in Pakistani small and medium enterprises , World Academy of Science, Engineering and Technology, International Journal of Economics and Management Engineering, 10 (8).

[25] Erturk, M., Tuerdi, M., \& Wujiabudula, A. 2016. The Effects of Six Sigma Approach on Business Performance: A Study of White Goods (home appliances) Sector in Turkey. Procedia - Social and Behavioral Sciences, 229, 444 - 452

[26] Cheng, J.L. 2007.Comparative Study of Local and Transnational Enterprises in Taiwan and their Implementation of Six Sigma. Total Quality Management and Business Excellence, 18, 793-806.

[27] Cheng, J.L. 2013. Linking Six Sigma to business strategy: an empirical study in Taiwan. Measuring Business Excellence, 17, 22-32.

[28] Prabhushankar, G. V., Devadasan, S. R. and Shalij, P. R. (2008), -Six Sigma in Indian Automotive Components Sector: A Survey ${ }^{\text {ee }}$, ICFAI Journal of Operations Management, 7(3), 18-37.

[29] Sambhe, R.U. and Dalu, R.S. (2011)_An empirical investigation of Six Sigma implementation in medium scale Indian automotive enterprises', Int. J. Productivity and Quality Management, 8(4), 480-501.

[30] Sambhe, R.U. 2012. Journey of Six Sigma in Indian SMEs-Literature Snapshots , International Journal of Engineering and Innovative Technology (IJEIT) 2(2), ISSN: 2277-3754

[31] Kwak, Y .H. and Anbari, F. T. 2006. -Benefits, obstacles, and future of six sigma approachll, Technovation, 26, 708-715.

[32] Chakravorty, S.S. 2009. Six Sigma programs: An implementation model', International Journal of Production Economics, 119(1), 1 - 16.

[33] Mahanti, R.,\& Antony, J. (2009).Six Sigma in the Indian software industry: some observations and results from a pilot survey. The TQM Journal, 21, 549 - 564.

[34] Anbari , F.T. and Kwak , Y.H. 2004. Success factors in managing six sigma in projects . Paper presented at the Project Management Research Institute . London.

[35] Zu , X Robbin , T.L. and Frendall , L.D. 2010. mapping the critical links between organizational culture and TQM six sigma practices, International Journal of Production Economics , 123 (1) , 86-106.

[36] Warfield, J.N. 1974. Developing interconnection matrices in structural modeling. IEEE Transactions on Systems, Man, and Cybernetics, (1), 81-87. 